\title{
COMPARATIVE STUDY OF BUSINESS EXCELLENCE FRAMEWORKS AND AWARDS IN SOUTHEAST ASIAN COUNTRIES
}

\author{
Budi Sulistyo* \\ Faculty of Industrial Engineering, Telkom University \\ Husni Amani \\ Faculty of Industrial Engineering, Telkom University \\ Sri Widaningrum \\ Faculty of Industrial Engineering, Telkom University \\ Musli Mohammad \\ Faculty of Mechanical and Manufacturing Engineering, \\ Universiti Tun Hussein Onn Malaysia (UTHM) \\ Rasidi Ibrahim \\ Faculty of Mechanical and Manufacturing Engineering, \\ Universiti Tun Hussein Onn Malaysia (UTHM)
}

\begin{abstract}
Many countries have initialized and adopted the business excellence framework to encourage high-quality achievements and be recognised internationally, including in Southeast Asian Nations (ASEAN). ASEAN as an economic and political organization of 11 countries located in Southeast Asia, established a business excellence framework to promote international organizational excellence and serve as national quality awards, which most of them adopted the Baldrige Excellence Framework (BEF). This study utilizes the accumulation and analysis of qualitative information using several sources and evidence from the business excellence frameworks and awards in ASEAN countries. This paper presents analytical comparisons of various aspects of the framework, such as their goals, award and recognition, categories, and score points (scores). It also discusses the similarities and differences among them.
\end{abstract}

Keywords: business excellence framework, quality award, Baldrige, Southeast Asian.

Received: 20 June 2019

Accepted: 26 August 2021

https://doi.org/10.33736/ijbs.4288.2021 * Corresponding author: Faculty of Industrial Engineering, Telkom University, Bandung, Indonesia; Tel: (62) 811216332; E-mail:
budisulis@telkomuniversity.ac.id 


\section{INTRODUCTION}

There are various ways to improve operation and provide value to stakeholders, including by implementing business excellence models through management systems and organizational processes development. These models involve achieving organizational excellence results through the successful consolidation and application of a range of improvement initiatives through approach, method, or technique (Mann et al., 2012b). Business excellence is also identified as a comprehensive practice in managing organizations and achieving results based on a set of fundamental concepts or values. These practices evolved into a framework as to how excellent organizations must operate (Mann et al., 2012a). Business excellence has been developed through extensive studies to assess and improve their highest work practices and performance (Mohammad et al., 2011). Many countries have developed their models and used this as a framework for assessing and recognizing organizational performance, which includes selecting high performing organizations for national awards and providing feedback on the performance of its applicants (Jayamaha et al., 2009). They also develop and embrace the business excellence framework to encourage the evolution of the products and services with high quality (Mohammad, 2019), which that the adoption of business excellence has had a positive impact on organizational practices and outcomes (Mann, Adebanjo, Laosirihongthong, \& Punnakitikashem, 2011). Three of the most famous and widely used frameworks are the Deming Prize, the Baldrige Excellence Framework (BEF), and the EFQM Excellence Model (Adebanjo et al., 2015; Krittanathip et al., 2013; Talwar, 2011). As of 2016, 94 excellence models and national quality awards in 83 countries had adopted the business excellence framework, including in Southeast Asian countries (Mann, Adebanjo, \& Tickle, 2011).

The Association of Southeast Asian Nations (ASEAN), which was established on 8 August 1967 and had 11 member countries, is firmly committed to accelerating the economic growth, social progress and cultural development in the region as stated in its aims and purposes. Since the 1990s, ASEAN countries have been established a framework and presented the national quality award to promote quality and serve as models of the TQM framework, which most of them were adopted from BEF (Mohammad et al., 2011). Moreover, two of these countries, Singapore and Thailand, are considered as having the most advanced business excellence organizations in Asia by the Asian Productivity Organization in 2018 (Tickle et al., 2016).

Business excellence framework that recognizes excellent organizational performance has emerged as an essential component of strategies to increase productivity and quality in many countries is also known as a prime contributor to productivity growth through its holistic approach that links enablers to results (Mann, 2016). The benefits of achieving business excellence in several fields have had a lot of impact on business management and results ( Mann, Adebanjo, Laosirihongthong, \& Punnakitikashem, 2011).

The discussion aspects of the business excellent frameworks in this paper will contribute to the understanding and enrichment of current programs in the ASEAN countries. Also, the concept and practices of BEF that have been exercised by the countries give deep insights to this paper as well. Past studies of the comparison business excellence frameworks have been done by several experts (Basmenj et al., 2013; Dodangeh et al., 2012; Jayamaha et al., 2009; Mann, Adebanjo, \& Tickle, 2011; Mohammad \& Mann, 2010; Shrouty \& Tiwari, 2017; Talwar, 2011; Tan, 2002; Toma \& Marinescu, 2018; Jankalová \& Jankal, 2018; Mohd Nasir, 2017), but none of them comparing the 
ASEAN countries, in addition, this paper will discuss and analyze the BEF among the ASEAN countries. Identification of critical success factors of BEF implementation in different ASEAN countries for future study will contribute further to the knowledge and practices of business excellence frameworks.

\section{LITERATURE REVIEW}

Business excellence framework or formerly called Total Quality Management is the current term to help communicate the importance of the word "excellence" in all aspects of the business, not just product quality and process (Mann et al., 2012b). These frameworks are used to measure how well business excellence elements of success are embedded in an organization. The Business Excellence Framework, which recognizes excellent organizational performance, has emerged as a significant part of the productivity and quality promotion strategies of many countries. (Asian Productivity Organization Tokyo, 2002), and provides input on things that must be improved and further developed and also provides a holistic method for handlers to direct business and lead to sustainable and measurable success. In this case, the business excellence framework functions as an internal business framework, it's practised as an overarching framework for managing and/or aligning multiple improvement initiatives within the organization (Mohammad et al., 2011). The business excellence framework is also holistic and focuses on all areas and dimensions of the organization, specifically the factors that drive performance. It provides a framework to assist the adoption of business excellence principles and an effective way to measure how thoroughly this adoption has been incorporated. According to Mohammad (2019), the framework has three main purposes: Guidance towards business excellence, assessment and awards, and an overarching approach for managing and aligning various organizational improvement initiatives.

The framework is most widely used as a tool for assessment and the foundation to guide organizations in achieving sustainable world-class awards. It's identified that the business excellence framework is currently being adopted by 94 national quality/business excellence awards in 83 countries (Mohammad et al., 2011). The Deming Prize as an excellence award was introduced in 1951, followed by the Canada Quality Award in 1984. These models were implemented in the US by establishing Malcolm Baldrige National Quality Award (MBNQA) in 1987 and the Australian Quality Awards in 1988. The European Quality Award based on the European Foundation for Quality Management (EFQM) excellence model, was then set up in 1991. Simultaneously with this era, several countries in Asia also evolved their quality framework during the 1990s, mostly by adopting the EFQM or Baldrige Excellence Framework (BEF) as their references. These frameworks have helped many organizations to improve their processes, customer, and improvement orientations. The BEF, EFQM Excellence Model and the Deming Prize are recognized worldwide and considered as the mothers of other national quality and business excellence awards (Talwar, 2011).

To raise the level of quality awareness and adoption of such business excellence, the custodian in each country is in charge of developing and deploying a framework and conducting award programs (Mann, Adebanjo, Laosirihongthong, \& Punnakitikashem, 2011). Several countries, like Singapore, and Malaysia, have developed business excellence models tailored to their individual needs and characteristics (MPC, 2019; Enterprise Singapore, 2019). This model is used as a frame of reference for assessing organizational performance and as a basis for awarding national awards. 
This national excellence award is based on a business excellence model that collected with various criteria and sub-criteria assessment. (Ghicajanu et al., 2015).

In ASEAN, most countries have developed excellence framework mainly based on BEF, since this framework symbolizes the highest standards of total quality management (Mann, Adebanjo, Laosirihongthong, \& Punnakitikashem, 2011; Tickle et al., 2016; Shrouty \& Tiwari, 2017). The BEF Criteria help identify company strengths, seek out corporate opportunities and seek opportunities for improved processes and outcomes that impact stakeholders, customers, employees, owners, suppliers, as well as the community. Thousands of organizations around the world use the Baldrige Excellence Framework to improve and get sustainable results (Tickle et al., 2016). The BEF criteria have been adopted or used as a model at both the state and local levels, as well as internationally. The criteria are more comprehensive and less prescriptive than the other instruments. The criteria model places greater emphasis on continuous improvement, customer focus, and strategic quality planning (Pannirselvam \& Ferguson, 2006). Criteria for Performance Excellence 2019-2020 edition divided into six inter-related process categories and a results category, represent seven critical aspects of managing and performing as an organization: The criteria consist of seven categories, which focus on the important elements of any high-performing organization (Blazey \& Grizzell, 2019):

1) Leadership, which examines senior leaders' actions, the governance system, and societal responsibilities.

2) Strategy, which examines the development of strategy development and strategy implementation

3) Customer, which examines the development of the voice of customers and customer engagement.

4) Measurement, analysis, and knowledge management, which examines how an organization measure, analyze, and improvement of organizational performance and information \& knowledge management.

5) Workforce, which examines how an organization engages its workforce and set a workforce environment.

6) Operations, which examines how an organization designs, manages and improves its work processes and operational effectiveness.

7) Results, which examines an organization's performance and improvement in all key area results of product and process, customer, workforce, leadership \& governance, and financial and market result.

Within each category are a set of questions that ask the organization to describe the approaches used to run the organization to ensure and improve competitive performance, how these approaches are executed or deployed throughout the organization, and the results obtained from such deployment. The BEF Criteria overview structure version 2019-2020 are represented in Figure 1 by the arrows leading to and from the eight constructs. To reach the business excellence level, an integrated set of development programs and tools should be provided to assist organizations in improving in each category of business excellence, these ideally would include awards for each category (Mann, 2016).

The seven BEF categories are subdivided into items and areas to address, each focusing on a major requirement (Blazey \& Grizzell, 2019). There are 17 Criteria items, which are divided into three 
groups according to the kinds of information: The Organization Profile (to define the organization environment), Process items (to define organization's processes in category 1-6), and Results items (to report results for the organization's processes required in category 7). The categories and items in BEF are scored based on evaluation for the process and the dimensions of the result (Baldrige Performance Excellence Program, 2019). The total score for categories and items of BEF is 1000, it's divided into different point values for each category and item. The process items have a total score of 550 and the results item has 450 points, while the Organization Profile item is not included in the score calculation.

Figure 1: Baldrige Excellence Framework 2019-2020

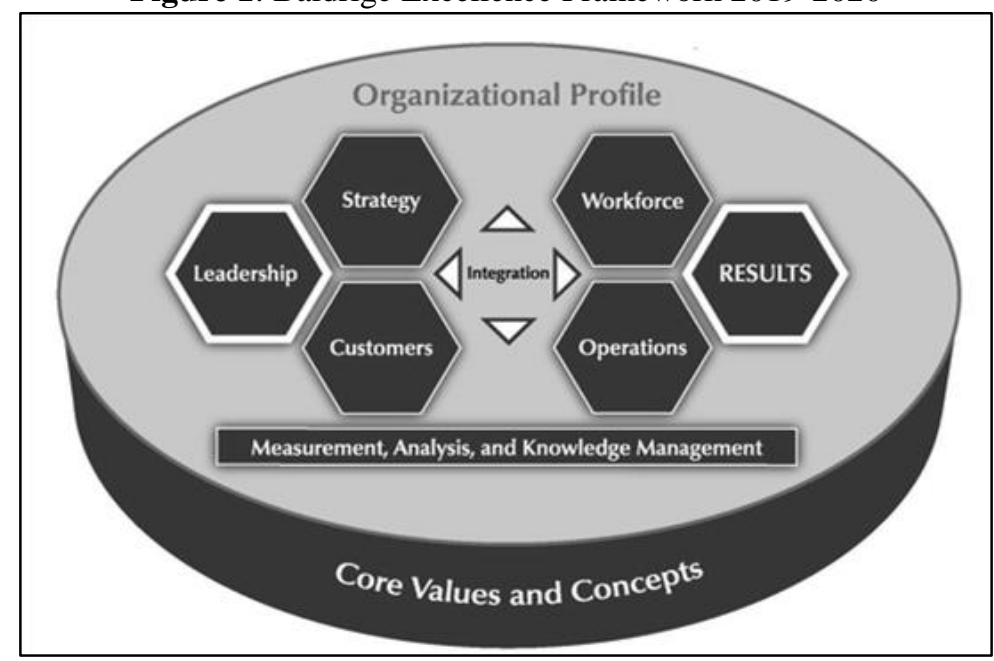

Source: Baldrige Performance Excellence Program, 2019

\section{METHODOLOGY}

The objective of the paper is to expose and compare business excellence models in ASEAN countries. The research shows the key aspects of each business excellence model, followed by their comparison. To achieve the previous goals, This research used a qualitative method in which primary data of Indonesia KPKU was collected from a survey and an extensive interview of 43 Indonesia SOEs executives who had background knowledge and experiences of KPKU implementation in their own companies. Meanwhile, data of business excellence frameworks implemented in other ASEAN countries were obtained from multiple secondary sources of databooks and academic journals, and articles from the domains of business excellence framework through desk research by using the internet and research databases (Emerald Insight, ScienceDirect, and Springer Link), although for some references have text processing problems with non-English words. 


\section{RESULTS AND DISCUSSION}

This research presents the features and attributes of the six frameworks and awards in terms of the following aspects: objectives and concepts, criteria and scoring system, evaluation dimensions, and award implementation as seen in Table 1. All the frames are initially based on a BEF model with or without modifications, such as the change of titles of some definitions or the model's sub-criteria but without any substantial alteration on its approach. Note that the primary benefit of adopting from a highly reputable model is that the framework mostly reflects the best management practices (Tan, 2002).

Table 1: Initial Reference Business Excellence Frameworks and Awards

\begin{tabular}{|c|c|c|}
\hline Excellence Frameworks & Excellence Awards & Initial Reference Model \\
\hline $\begin{array}{l}\text { Baldrige Excellence Framework } \\
\text { Singapore Business Excellence } \\
\text { Framework }\end{array}$ & $\begin{array}{l}\text { Baldrige Award } \\
\text { - } \quad \text { Singapore Quality Award (SQA } \\
\text { - } \quad \text { Singapore Quality Class (SQC) }\end{array}$ & $\begin{array}{l}\text { Deming Prize } \\
\text { Baldrige, EFQM Excellence } \\
\text { Model, Japan Quality Award } \\
\text { and Australian } \\
\text { Organizational Excellence } \\
\text { Awards }\end{array}$ \\
\hline $\begin{array}{l}\text { Malaysia Business Excellence } \\
\text { Framework } \\
\text { Thailand Excellence Framework } \\
\text { Indonesia Excellence } \\
\text { Framework }\end{array}$ & $\begin{array}{l}\text { Malaysia Industry Excellence } \\
\text { Award (AKI) } \\
\text { Thailand Quality Award (TQA) } \\
\text { Indonesia Performance Excellence } \\
\text { Award (KPKU) }\end{array}$ & $\begin{array}{l}\text { Baldrige, Deming’s Prize } \\
\text { Baldrige, SQA } \\
\text { Baldrige }\end{array}$ \\
\hline $\begin{array}{l}\text { Philippine Excellence } \\
\text { Framework } \\
\text { Vietnam Excellence Framework }\end{array}$ & $\begin{array}{l}\text { Philippine Quality Award (PQA) } \\
\text { Vietnam National Quality Award } \\
\text { (VQA) }\end{array}$ & $\begin{array}{l}\text { Baldrige, Australian Business } \\
\text { Excellence Award } \\
\text { Baldrige }\end{array}$ \\
\hline
\end{tabular}

Source: TQA, 2018; MPC, 2019; Enterprise Singapore, 2019; Kementerian BUMN, 2017; TCVN Vietnam, 2016; PQA, 2017.

\subsection{Singapore Quality Award (SQA)}

The Singapore business excellence framework as shown in Figure 2, covers the relationships of seven key performance drivers in business excellence: Leadership, Strategy, Customers, People, Processes, Knowledge and Results - and how they impact each other. Organizational leadership sets the vision and culture to achieve organizational excellence through understanding and meeting the needs and interests of customers. In turn, it is possible to develop people and the ability of the regulatory process to achieve the intended results. To maintain this result, organizations need to innovate and learn through effective knowledge management.

Implementation of excellence depends on the needs and strategies of the organization, whether to choose a certification for capability improvement or to get awards as proof of organizational excellence. The SQA gives the award to the organizations that demonstrate the highest standards of business excellence. The Singapore Quality Award is based on the Singapore business excellence framework that was adopted from the BEF Model, the EFQM model of excellence, and the Australia Organizational Excellence Framework. The aim of the excellence model is that the 
organization will be capable of reaching world-level performance standards through strengthening management systems and increasing capabilities and competitiveness (Porter \& Tanner, 2004).

Each organization can submit recognition, namely business excellence certificate (BE Certificate) and business excellence award (BE Award). BE Certificates are the groundwork for pursuing the Singapore Quality Class (SQC), the necessary foundation, before deepening their niche capabilities in Innovation, People, and Services. The BE Awards recognize organizations that exhibit outstanding performance based on holistic BE standards, with this award organizations must obtain a specific mark to make the Singapore Quality Award (SQA) with the category of niche awards in specific requirements on innovation, people and service. The Asian Productivity Organization (APO) described the SQA as the most successful award based on strong commitment and support of senior leaders (Prime minister and CEOs) and the high tier of experience of administrators (Enterprise Singapore) and high level of resource support (Mann, 2016).

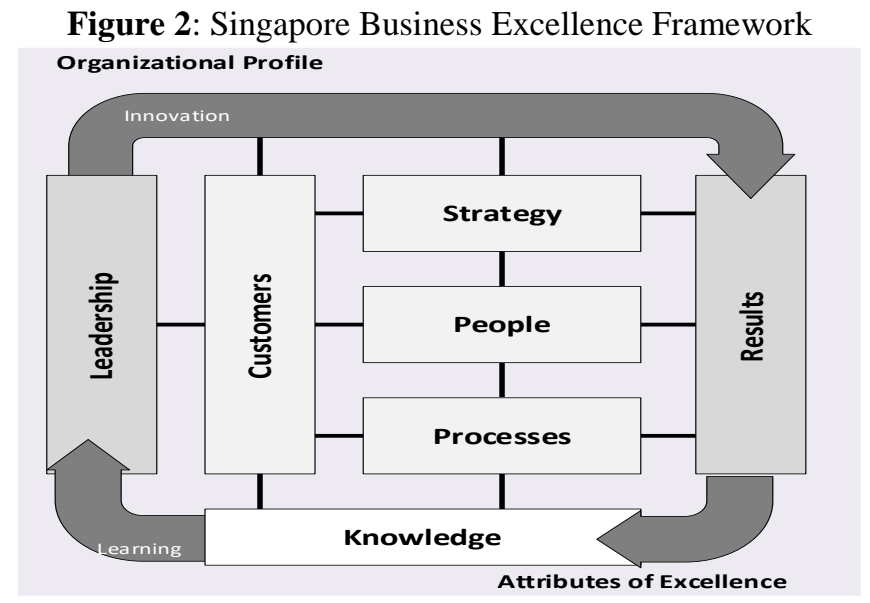

Source: Enterprise Singapore, 2019

\subsection{Malaysia Industry Excellence Award (AKI)}

The Anugerah Kecemerlangan Industri (AKI) or industry excellence award was presented by the Ministry of International Trade and Industry (MITI) in 1991. It was one of the first steps by the government to recognize outstanding Malaysian companies and to promote commercial enterprises to enhance their management practices, eventually contributing to an improvement in the quality of merchandise and services. Over the years, AKI has gained a reputation for being the nation's premier corporate recognition award. The AKI is based on the business excellence framework, as shown in Figure 3, for guiding the criteria in the valuation procedure.

Malaysia business excellence framework covers seven criteria, which are interlinked and affect each other. Leadership drives the organization to achieve results through the effective process of Strategy, Information, Customers, Workforce and Process. The organization Learn, Innovate and Transform from the Results to improve all other areas of focus, in turn, will improve the Results. The Criteria is guided by the Guiding Principles of world-class performance attributes. 
Organizational Overview is the background of organizations which consist of the organization's direction, internal and external factors that affected the organization (Malaysia Productivity Corporation (MPC), 2020). The winner of the AKI award selected from among the winners of the categories: Manufacturing sector award (domestic companies with various sales turnover), Service sector award (local companies with multiple sales turnover), Open Category Award (multinational companies in manufacturing and service sectors) and Most Promising Award.

Figure 3: Malaysia Business Excellence Framework 2020-2025

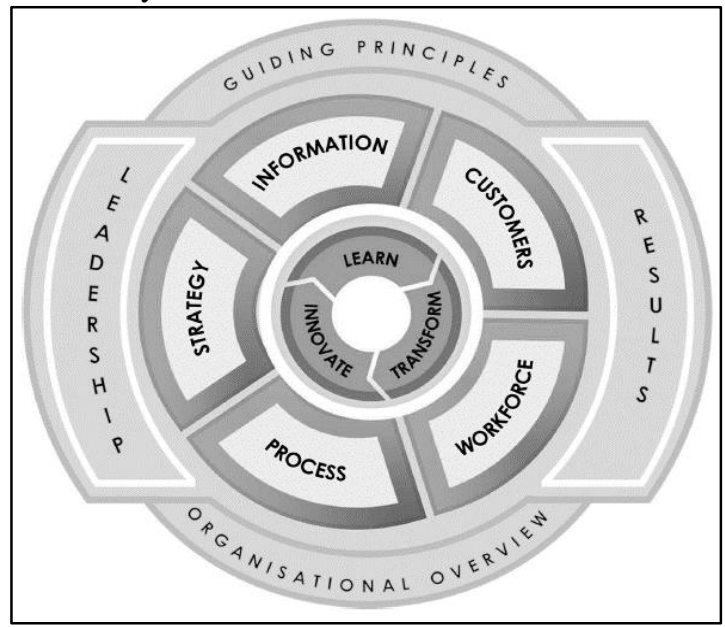

Source: (MPC, 2019)

\subsection{Thailand Quality Award (TQA)}

The TQA was initiated by the Thailand Productive Institute (FTPI) and the National Center Science and Technology Development Agency (NSTDA) and consulted by the Singapore Quality Award (SQA) (Krittanathip et al., 2013). Thailand Quality Award (TQA has therefore put in the strategic plan to increase the country's productivity, both public and private sectors to pass around, support and push for organizations in the manufacturing and service sectors (TQA, 2018). TQA, which has been well-built and implemented since 2002, adopted the BEF with the minor modification. TQA has a technical basis and the awarding process with the objectives: to support the implementation of the national quality award guidelines for improving competitiveness, to announce the honour to organizations that achieve world-class standards, to encourage learning and exchange excellent practices, and to show the international commitment to raising the standard of excellence in management. TQA criteria of requirements cover seven critical aspects of organizational management and operation (Subdivided into six categories with related relationships and one result).

\section{a. Indonesia Performance Excellence Award (KPKU)}

Indonesia Performance Excellence Award or Kriteria Penilaian Kinerja Unggul (KPKU) was established by the State-owned Enterprise (SOEs) Ministry Indonesia in 2012. KPKU has a 
straightforward goal, which is to help companies to be able to improve their performance with a criteria guide designed and applied in all business sectors and types of SOEs. The KPKU criteria derived from the Indonesia Excellence Framework, as shown in Figure 4, which are adopted from BEF criteria with the objectives to encourage and assist companies to improve sustainable performance and possess the competitive advantage of the company, which in the end it can be demonstrated by achieving superior results. Recently, KPKU is only presented to the state-owned enterprises that have successfully implemented quality management systems, in any category and sector.

Figure 4: Indonesia Excellence Framework 2017

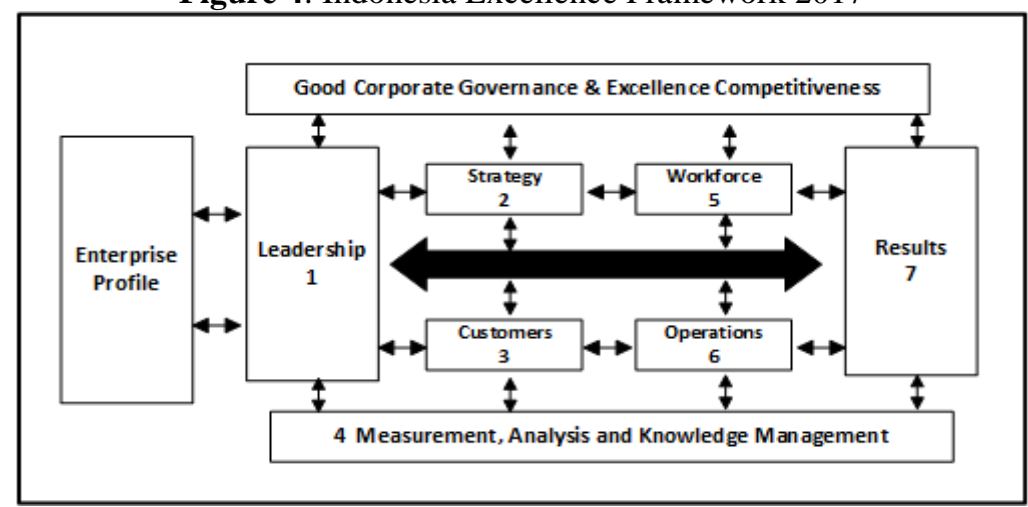

Source: Kementerian BUMN, 2017

\subsection{Philippine Quality Award (PQA)}

The PQA was formed by the Philippine government in 2001 to be an integrated framework for organizations with world-level performance. The framework was developed as performance management and organization excellence standard that could ultimately improve performance and productivity within the context of building a national system, both at the level of public and private organizations (PQA, 2017). PQA is derived from the BEF with no changes or alterations from the original edition.

\subsection{Vietnam National Quality Award (VQA)}

VQA was developed by the Ministry of Science and Technology on the occasion of the quality and productivity movement in the first Vietnamese quality decade between 1995 - 2005. VQA criteria are based on modern principles (customer-oriented, process management, and systematic management) and the current management method (TQM). The objectives of the VQA are to review, evaluate and award companies with excellent performance and outstanding achievements in innovating, improving quality and contributing to the productivity and quality of the country, as well as respecting companies with outstanding results in improving product quality and service, competitive capacity and performance. VQA is derived from the Vietnam Excellence Framework 2016 version, which is also adopted from the Baldrige without any modifications in the term of categories, but slightly in the score and the number of the items. 


\subsection{Business Excellence Frameworks Comparison}

A comparative analysis of the frameworks of the seven-quality business excellence was performed by sorting and grouping by the categories and items of each framework and then compared to Baldrige's category order, as shown in Table 2. Similar to BEF, all six-quality awards address the general issue started with the category "Leadership" and closing with the category "Results." However, compared to other awards, SQA shows a different sequence of categories with BEF. In SQA category 2 is "customers," category 3 is "strategy," category 4 is "people," category 5 is "process," and category 6 is "knowledge" without measurement analysis and information. While in AKI, category 3 and 4 switched positions with the BEF and category 3 is defined as Information, as a substitute for the naming of category 4 BEF measurement, analysis and knowledge management. Even though all the six models were adopted from BEF, only two models were similar to BEF without any changes, namely KPKU and PQA. While SQA has a different organization of categories, the number and score of items with the BEF, AKI and TQA have the same category and item arrangement with the BEF, but both have a different arrangement in item points. The VQA has the same category arrangement, but there is an item added in category 7 and point arrangement that is somewhat different from the BEF.

SQA has seven categories, but compared to other frameworks, it has 21 items with very different arrangements and scores. Another framework that also has a different number of items is VQA, although it has only 1 item more than the BEF.

As described by the Asian Productivity Organization (APO) that SQA is one of the most successful awards in Asia, the framework has a different arrangement of items with the BEF. While another framework has only two items in each of the process categories and five items in each of the results categories, the SQA has three items in category 1 (leadership), category 2 (customers), and category 5 (processes), and it has four items in category 4 (people), and category 7 (results), while category 3 (strategy) and category 6 (knowledge) remain have two items. Interestingly, the Vietnam framework has six items for category 7 (results), which is an addition to the operational efficiency results (item 7.5).

There is no difference between BEF and other frameworks in naming the categories; Leadership, Strategy, Customers, and Results. While the category Measurement, Analysis and Knowledge Management, is called category Knowledge in Singapore, and category Information in Malaysia. As for the category Workforce, in Singapore and Malaysia is named category People, and for the category Operations, it is called the category Process. 


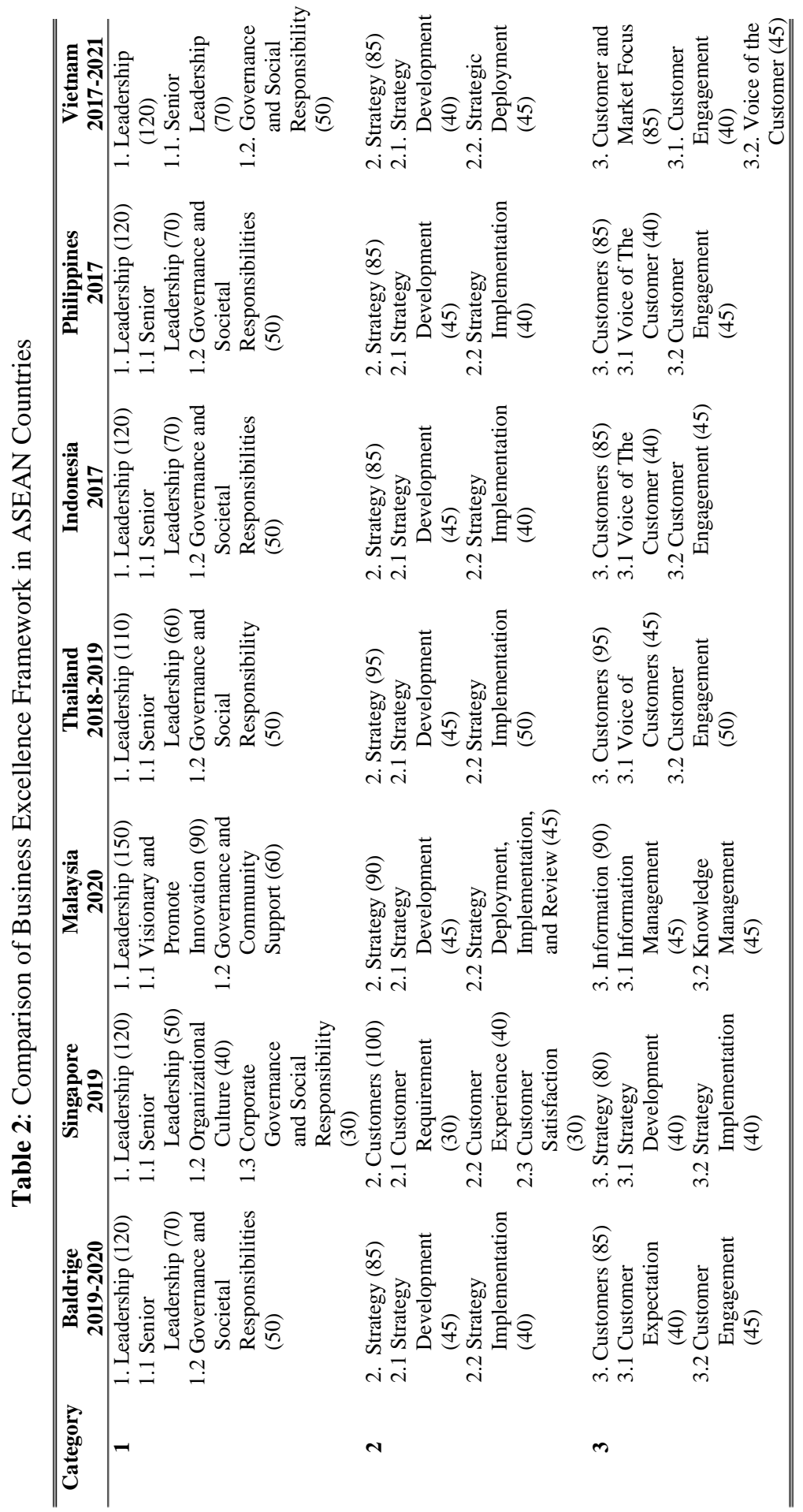




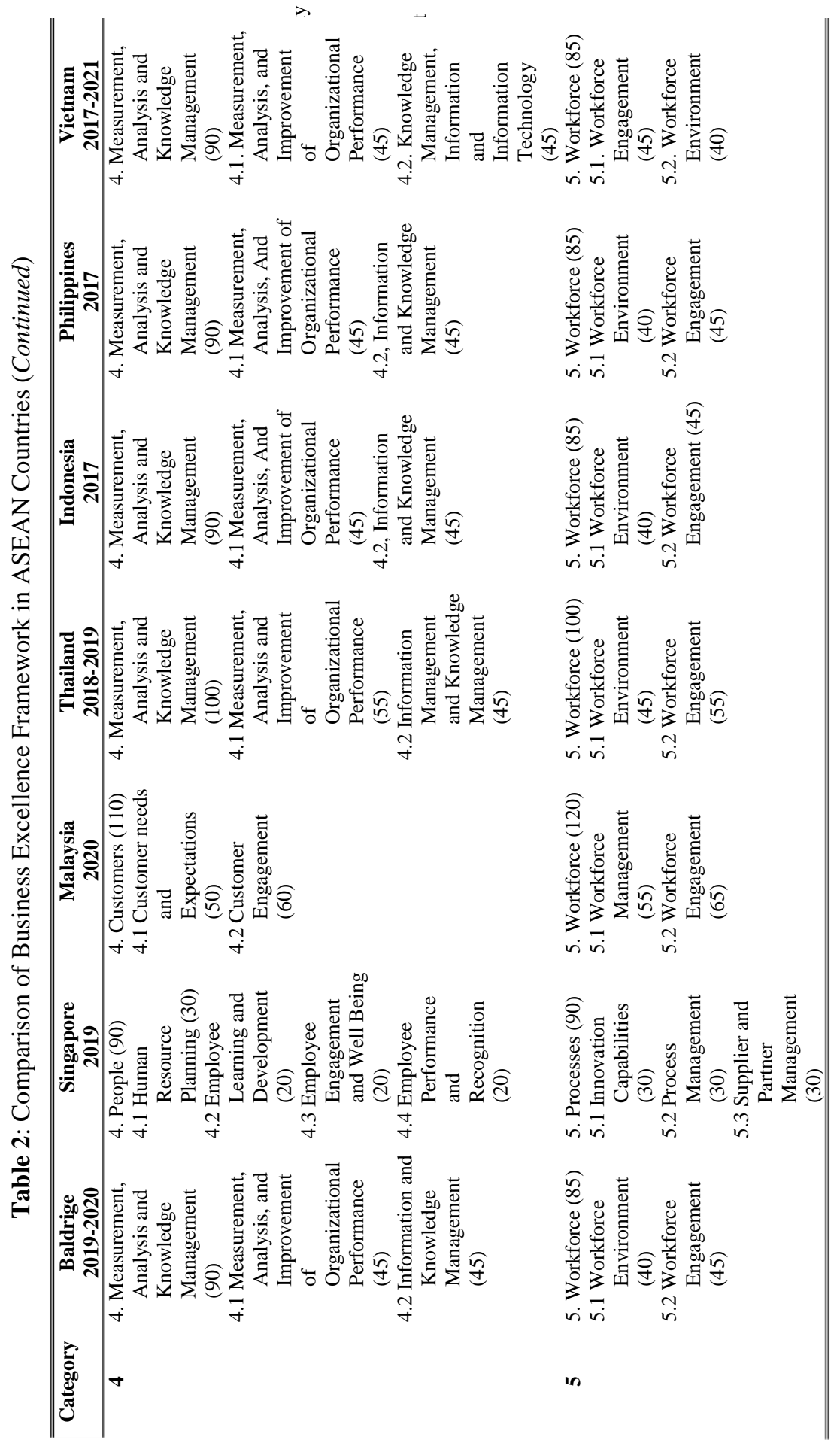




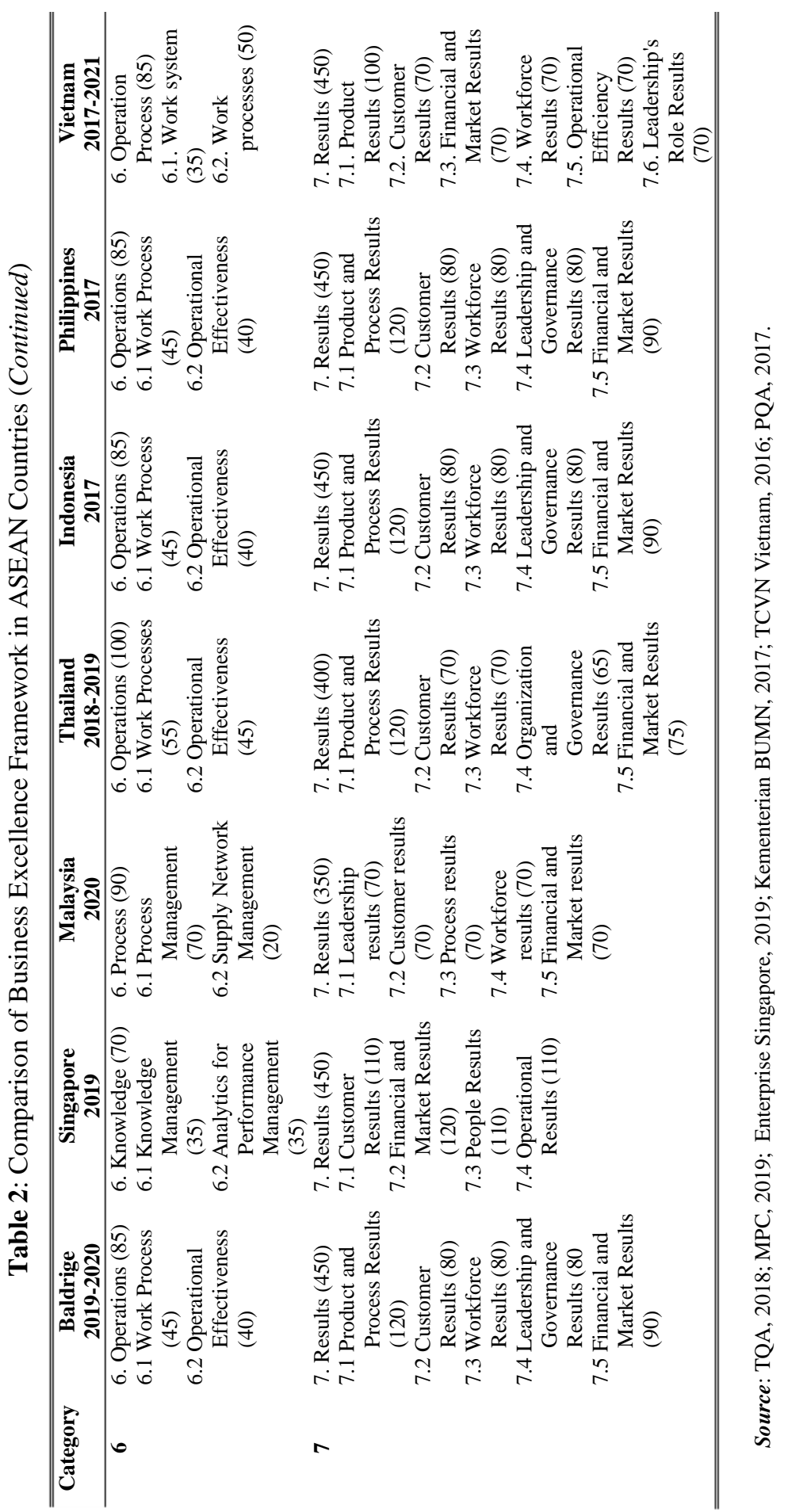


As seen in Table 3, all the national awards and frameworks have a total score of 1000 points. They all have seven categories with a different combination in the number of items, and different composition of the enabler and the result points.

Table 3: Score Comparisons

\begin{tabular}{lcccc}
\hline \hline \multicolumn{1}{c}{ National Award } & $\begin{array}{c}\text { Number of } \\
\text { Categories }\end{array}$ & $\begin{array}{c}\text { Number } \\
\text { of Items }\end{array}$ & $\begin{array}{c}\text { Enabler } \\
\text { Points }\end{array}$ & $\begin{array}{c}\text { Result } \\
\text { Points }\end{array}$ \\
\hline Singapore Quality Award (SQA) & 7 & 21 & 550 & 450 \\
Malaysia Industry Excellence Award (AKI) & 7 & 17 & 650 & 350 \\
Thailand Quality Award (TQA) & 7 & 17 & 600 & 400 \\
Indonesia Performance Excellence Award & 7 & 17 & 550 & 450 \\
(KPKU) & 7 & 17 & 550 & 450 \\
Philippine Quality Award (PQA) & 7 & 18 & 550 & 450 \\
Vietnam National Quality Award (VQA) & 7 & & \\
\hline \hline
\end{tabular}

Source: TQA, 2018; MPC, 2019; Enterprise Singapore, 2019; Kementerian BUMN, 2017; TCVN Vietnam, 2016; PQA, 2017.

SQA has 21 items, more numerous than another, followed by VQA with 18 items, while other awards have 17 items, the same amount as the BEF. AKI has 650 points in the enabler category, followed by TQA with 600 points, and other NQAs have 550 points, the same enabler points as the BEF, consequently the total score of the result category for the AKI and TQA are the smallest compared to the others. In the result category, item 7.1, product and process results have the biggest score (120) in Thailand, Indonesia, The Philippine, and Vietnam framework, while in Singapore the biggest score is item 7.2 Financial and Market Results (120), and the other items remain 110 points. In Malaysia, all five result items have the same score of 70 points.

The criteria for the BEF consists of three versions: The 2019-2020 Baldrige Excellence Framework (Business/Nonprofit). The 2019-2020 Baldrige Excellence Framework (Education) and the 2019-2020 Baldrige Excellence Framework (Health Care). All the versions include the Baldrige Criteria for Performance Excellence, core values and concepts, and guidelines for evaluating an organization's processes and results in the category of business, nonprofit, and government.

As it's pointed out in Table 4, the award in ASEAN countries, just like the Baldrige award, is intended for all types of companies both manufacturing and services, with different categories of public and private companies, small and large companies, and to profit and social companies.

In contrast to other countries, in Indonesia, the national award or KPKU has a specific objective of supporting state-owned enterprises (SOEs) to improve their performance through a framework of criteria designed to apply to all business sectors and types of SOEs, either private or public, service provider or manufacturing sector in oil-mining, energy, planting, forestry, heavy industries, banking, telecommunications, tourism, transport.

With this categorization, awards that are competed for, in addition to the highest awards, are also given based on the type of group, such as in Malaysia there is an award for manufacturing and service sectors and in the Philippines which are presented for the public and private sectors. 
Table 4: Award Eligible Applicants

\begin{tabular}{|c|c|}
\hline National Award & Applicants \\
\hline Baldrige Award & $\begin{array}{l}\text { Organization in category: business, nonprofit, and } \\
\text { government. }\end{array}$ \\
\hline Singapore Quality Award (SQA) & Organizations in the public and private sector \\
\hline Malaysia Industry Excellence Award (AKI) & $\begin{array}{l}\text { Separate criteria and categories by sectors } \\
\text { (manufacturing, services, and multinational company) }\end{array}$ \\
\hline Thailand Quality Award (TQA) & Organization in the manufacturing and service sector \\
\hline $\begin{array}{l}\text { Indonesia Performance Excellence Award } \\
\text { (KPKU) }\end{array}$ & State-owned enterprise (SOEs) \\
\hline Philippine Quality Award (PQA) & $\begin{array}{l}\text { Public and private sector (small, medium and large } \\
\text { enterprise) }\end{array}$ \\
\hline Vietnam National Quality Award (VQA) & $\begin{array}{l}\text { Separate by enterprise forms: big production, small and } \\
\text { medium production, large services, small and medium } \\
\text { services in the private and public sector. }\end{array}$ \\
\hline
\end{tabular}

Source: TQA, 2018; MPC, 2019; Enterprise Singapore, 2019; Kementerian BUMN, 2017; TCVN Vietnam, 2016; PQA, 2017.

In this study, it was distinctly shown in Table 5 that all ASEAN excellence framework and quality awards are supported by their governments. Most of these awards are governed by the ministry or department, and some of the award organizers are in a particular body, such as Enterprise Singapore, AKI Council Malaysia, KPKU Indonesia, and institute or academy assigned by the government. A substantial commitment from the government is necessary to ensure the successful implementation of a national quality award (Tan, 2002). It's also noticed by the APO that to achieve the success of a country's performance excellence, the chief executive of each country must support through the implementation of quality improvement programs and awarding of organization business excellence performance (Asian Productivity Organization Tokyo, 2002).

Enterprise Singapore is the government agency that supports the development of enterprises. It works to develop capabilities, evolve and internationalise with dedicated companies. It also supports Singapore's rise as a centre for global commerce and startups. Enterprise Singapore continues to create confidence in Singapore's goods and services through quality and standards as the body for national standards and accreditation.

The Thailand Productivity Institute is an organization under the Ministry of Industry established with its core mission is to utilise highly skilled, knowledgeable, and experienced staff to promote increased productivity in Thailand as a means of improving the nation's competitiveness. The institute provides international-standard services to help both public and private organizations achieve excellence. These include training and consulting services, productivity research and index, productivity promotion services, and International Cooperation with the Asian Productivity Organization (APO).

In Indonesia, the KPKU is organized by the Ministry of SOE and the assessment and evaluation are organized by the SOE Excellence Forum, where its members are the SOE employees who have the qualifications and competencies of the Baldrige excellence framework. 
Table 5: Administrative Organization

\begin{tabular}{|c|c|}
\hline National Award & Organizer \\
\hline Baldrige Award & The National Institue of Standards and Technology \\
\hline Singapore Quality Award (SQA) & Enterprise Singapore (ES) \\
\hline $\begin{array}{l}\text { Malaysia Industry Excellence Award } \\
\text { (AKI) }\end{array}$ & $\begin{array}{l}\text { Ministry of International Trade and Industry (MITI) as a } \\
\text { governing body, AKI Council as the organizer }\end{array}$ \\
\hline Thailand Quality Award (TQA) & $\begin{array}{l}\text { Ministry of Industry as a governing body, The National } \\
\text { Productivity Institue as quality award office }\end{array}$ \\
\hline Indonesia Performance Excellence & Ministry of State-Owned Enterprise as a governing body, SOE \\
\hline Award (KPKU) & Excellence Forum as the award organizer \\
\hline Philippine Quality Award (PQA) & $\begin{array}{l}\text { Department of Trade and Industry as implementing agency, } \\
\text { Philippine Society for Quality as administrator for the private } \\
\text { sector and Development Academy of Philippines as } \\
\text { administrator for public sector }\end{array}$ \\
\hline $\begin{array}{l}\text { Vietnam National Quality Award } \\
\text { (VQA) }\end{array}$ & $\begin{array}{l}\text { The Ministry of Science and Technology as a governing body, } \\
\text { Directorate for Standards Metrology and Quality (STAMEQ) as } \\
\text { a standing agency }\end{array}$ \\
\hline
\end{tabular}

Source: TQA, 2018; MPC, 2019; Enterprise Singapore, 2019; Kementerian BUMN, 2017; TCVN Vietnam, 2016; PQA, 2017.

Each country holds a different framework in setting the grade of recognition to each organization, including in determining the level based on the performance score obtained and the type of organization assessed. As seen in Table 6, some national awards present gratitude only to the companies that have achieved outstanding performance. Other awards provide various points of recognition for companies at several stages of their quality improvement efforts.

Organizations in Singapore, depending on their needs and strategies, may choose from the certification and award programs under the business excellence initiative to enhance their capabilities. Organizations on the business excellence journey are required to pursue the Singapore Quality Class (SQC) as a required foundation must score at least 400 points, before deepening their niche capabilities in Innovation, People and Service. To apply for the Business Excellence Award, an organization must score at least 700 points out of a 1000 point-scale to attain one of the: Singapore Quality Award (SQA), Innovation Excellence Award (IEA), People Excellence Award (PEA), and Service Excellence Award (SEA).

The winner of the Malaysia Prime Minister's Award, which is the highest achievement, will be selected from among the winners of the below categories; Manufacturing Sector Award, Services Sector Award, Open Category Award, Most Promising Award, and Industry4WRD Excellence Award (recognition to a company that has successfully implemented Industry 4.0 technologies and processes).

The highest level of recognition in the Philippines is the Philippine Quality Award for Performance Excellence (PQA), which is given to organizations in the private and public sectors which excel in quality and productivity. For the award below the PQA, there are Recognition for Mastery in Quality Management (role model for Philippine-base companies), Recognition for Proficiency in Quality Management (achieved significant progress in building sound processes), and Recognition for Commitment to Quality Management (demonstrates a serious commitment to total quality management). To perform excellently and become competitive to follow the framework of the PQA program, organizations start their journey by implementing the Philippine Quality Challenge 
(PQC) program, a program consisting of a Self-Assessment, Consultancy, and Recognition program.

Regarding the conditions for participating in the Vietnam National Quality Award, the applicant must be the enterprise that has been engaged in continuous production and business activities in Vietnam and have not violated the law in the nearest time. At the same time, enterprises must meet the seven criteria of the National Quality Award. An organization will be awarded the National Quality Silver award when businesses reach 600 points or more. The Golden prize award will be considered when organizations reach 800 points or more and are considered to be the best among enterprises that achieve national quality certificates in 4 types: big production, big service, small and medium production, small and fit.

Table 6: Level of Recognition Award

\begin{tabular}{ll}
\hline \hline \multicolumn{1}{c}{ National Award } & \multicolumn{1}{c}{ Level of Recognition } \\
\hline $\begin{array}{l}\text { Baldrige Award } \\
\text { Singapore Quality Award (SQA) }\end{array}$ & $\begin{array}{l}\text { Award Recipient } \\
\text { Singapore Quality Award with Special Commendation } \\
\text { (SQA SC), Business Excellence (BE) Awards, Singapore }\end{array}$ \\
& $\begin{array}{l}\text { Quality Class STAR, Singapore Quality Class with } \\
\text { Niche, Singapore Quality Class (SQC) }\end{array}$ \\
Malaysia Industry Excellence Award (AKI) & $\begin{array}{l}\text { Prime Minister's Award, Manufacturing Sector Award, } \\
\text { Services Sector Award, Open Category Award } \\
\text { (multinational company), Most Promising Award. }\end{array}$ \\
Thailand Quality Award (TQA) & $\begin{array}{l}\text { TQA, Thailand Quality Class Plus (TQC+), TQC Award } \\
\text { Indonesia Performance Excellence Award } \\
\text { IKPKU) }\end{array}$ \\
$\begin{array}{l}\text { Industry Leader, Emerging Industry leader, Good } \\
\text { Philippine Quality Award (PQA) }\end{array}$ & $\begin{array}{l}\text { PQA, Mastery in QM, Proficiency in QM, Commitment } \\
\text { in QM, Philippine Quality Challenge (PQC) }\end{array}$ \\
Vietnam National Quality Award (VQA) & Golden Prize, Silver or National Quality Award (NQA) \\
\hline \hline
\end{tabular}

Source: TQA, 2018; MPC, 2019; Enterprise Singapore, 2019; Kementerian BUMN, 2017; TCVN Vietnam, 2016; PQA, 2017.

Implementing business excellence is highly regarded by a majority of organizations as both an improvement tool and a management tool to support future competitiveness and long-term goals (Mann, Adebanjo \& Tickle, 2011). The Singapore Business Excellence Initiative was first launched in 1994 as a program of recognition to improve the capacities of organizations and to instil organizational competence in mindset. To date, more than 2,000 organizations in all categories have been recognized through business excellence awards and certifications (Enterprise Singapore, 2020), no wonder the Asian Productivity Organization (APO) described the SQA as one of the most successful awards in Asia (Mann, 2016). Another successful business excellence implementation in Vietnam. The Vietnam National Quality Award is the only government award on quality and is determined by the Prime Minister to encourage Vietnamese manufacturing, business and service enterprises of all advanced economic sectors. quality of goods and products, increase labour productivity to be competitive in the domestic and world markets. Winning enterprises must have shown significant performance in improving product quality and services and made great efforts to integrate into the regional and global economy and contribute to social development. For over the last 20 years there have been 690 award-winning enterprises, 188 winning gold awards and 128 enterprises receiving a certificate from the government. These 
national award practices encourage Asian countries to adopt business excellence to be primarily linked to increased competitiveness (Mann, Adebanjo, Laosirihongthong, \& Punnakitikashem, 2011).

\section{CONCLUSIONS}

The main models of national quality awards of the ASEAN countries have in common between them, and all countries have acquired and implemented a framework of business excellence to be utilized in the total quality management of their organizations. Almost all national awards in ASEAN were built by adopting the Baldrige Excellence Framework model, either 100\% corresponding to the original model or by changing the composition of the categories, the number of items and the point of the criteria used. Furthermore, in all ASEAN countries, the Governments hold a significant part in determining criteria, implementing and giving national awards, and supporting the successes of every organization in their country.

This paper provides perspectives to get to know and understand more about the model of business excellence/national awards in ASEAN countries, which can ultimately assist leaders in evaluating and improving the framework of business excellence. Because this paper only analyses six business excellence models, future research can be developed by comparing with more extensive models and frameworks, so that a more detailed analysis can be obtained.

\section{REFERENCES}

Adebanjo, D., Tickle, M., Laosirihongthong, T., \& Mann, R. (2015). A study of the use of business improvement initiatives: The association with company size and level of national development. Production Planning \& Control, 26(7), 507-524. https://doi.org/10.1080/09537287.2014.927931

Asian Productivity Organization Tokyo. (2002). The Quest for Global Competitiveness Through National Quality and Business Excellence Awards. https://www.apo-tokyo.org/00ebooks/IS-11_GlobalComp/IS-11_GlobalComp.pdf

Baldrige Performance Excellence Program. (2019). 2019-2020 Baldrige Excellence Framework: Proven Leadership and Management Practice for High Performance. Department of Commerce, National Institute of Standards and Technology (NIST). https://www.nist.gov/system/files/documents/2019/02/06/2019-2020-baldrige-excellencebuilder.pdf

Basmenj, F. A., Yusuff, R. M., Zulkifli, N., Ismaiel, Y., \& Sorooshian, S. (2013). Comparative Study on Quality Awards. Journal of Applied Sciences Research, 9(1), 44-45.

Blazey, M., \& Grizzell, P. (2019). Insights to Performance Excellence 2019 - 2020. ASQ Quality Press.

Dodangeh, J., Rosnah, M. Y., Ismail1, N., Ismail, Y. M., Biekzadeh, M., \& Jassbi, J. (2012). A Review on Major Business Excellence Frameworks. Technics Technologies Education Management, 7(3), 1386-1393.

Enterprise Singapore. (2019). Business Excellence Framework. http://imcs.sg/wpcontent/uploads/2020/04/ESG-Sharing_BE-Seminar_27-Nov-18_shared-edited.pdf

Enterprise Singapore. (2020). Business Excellence. https://www.enterprisesg.gov.sg/quality- 
standards/business-excellence

Ghicajanu, M., Irimie, S., Marica, L., \& Munteanu, R. (2015). Criteria for Excellence in Business. Procedia Economics and Finance, 23, 445-452. https://doi.org/10.1016/S22125671(15)00388-3

Jankalová, M., \& Jankal, R. (2018). Sustainability assessment according to the selected Business Excellence models. Sustainability, 10(10), 1-24. https://doi.org/10.3390/su10103784

Jayamaha, N., Grigg, N., \& Mann, R. (2009). A study of the validity of three major business excellence models in the Asia Pacific region. Total Quality Management and Business Excellence, 20(11), 1213-1227. https://doi.org/10.1080/14783360903247536

Kementerian BUMN. (2019). Kriteria Penilaian Kinerja Unggul (KPKU) 2019. https://jdih.bumn.go.id/unduh/S-08/S.MBU/2013.pdf

Krittanathip, V., Rakkarn, S., \& Cha-um, S. (2013). A Novel Cluster Analysis on National Quality Awarding in Asian Countries: Thailand, Japan, Singapore and Taiwan. Procedia - Social and Behavioral Sciences, 88, 13-19. https://doi.org/10.1016/j.sbspro.2013.08.476

Mann, R. (2016). Business Excellence Models and Awards for the Public Sector. Asian Productivity Organization. https://www.apo-tokyo.org/publications/ebooks/businessexcellence-models-and-awards-for-the-public-sector-a-guidebook-for-nationalproductivity-organizations/

Mann, R., Adebanjo, D., \& Tickle, M. (2011). Deployment of business excellence in Asia : an exploratory study. International Journal of Quality \& Reliability Management, 28(6), 604 627. https://doi.org/10.1108/02656711111141184

Mann, R., Mohammad, M., \& Agustin, M. T. A. (2012a). Implementing Business Excellence : A Guidebook for SMEs. In Asian Productivity Organisation. https://www.apo-tokyo.org/wpcontent/uploads/sites/3/2014/07/Implementing-Business-Excellence.pdf

Mann, R., Mohammad, M., \& Agustin, M. T. A. (2012b). Understanding Business Excellence: An awareness guidebook for SMEs. In Asian Productivity Organisation. https://www.apotokyo.org/wp-content/uploads/sites/3/2014/07/Understanding-Business-Excellence.pdf

Mann, R., Adebanjo, D., Laosirihongthong, T., \& Punnakitikashem, P. (2011). Awareness and impact of business excellence in Asia. Total Quality Management \& Business Excellence, 22(11), 1237-1258. http://dx.doi.org/10.1080/14783363.2011.624772

Mohammad, M. (2019). Convergence of ISO 9001 and Business Excellence. In IEOM Conference. Mohammad, M., \& Mann, R. (2010). National Quality / Business Excellence Awards in Different Countries (Issue August). http://www.nist.gov/baldrige/community/upload/National_ Quality_Business_Excellence_Awards_in_Different_Countries.xls

Mohammad, M., Mann, R., Grigg, N., \& Wagner, J. P. (2011). Business Excellence Model : An overarching framework for managing and aligning multiple organisational improvement initiatives. Total Quality Management \& Business Excellence, 22(11), 1213-1236. https://doi.org/10.1080/14783363.2011.624774

Mohd Nasir, H. B. (2017). State-Owned Enterprises: a Comparison Between the UK, Japan, and Malaysia. International Journal of Economics, Commerce and Management, 5(2), 114-130.

Malaysia Productivity Corporation. (MPC) (2019). Malaysia Business Excellence Framework 2020-2025. Malaysia Productivity Corporation. https://drive.google.com/file/d/1t3FkWThHtNt85-1I0KfIT85-uvgML6Fo/view

Pannirselvam, G. P., \& Ferguson, L. A. (2006). A study of the relationships between the Baldrige categories. International Journal of Quality \& Reliability Management, 18(1), 14-37. https://doi.org/10.1108/02656710110364468

Porter, L. J., \& Tanner, S, J. (2004). Assessing Business Excellence (2 ${ }^{\text {nd }}$ ed). Elsevier Butterworth- 
Heinemann.

Philippines Quality Award. (PQA) (2017). 2017-2021 PQA Criteria for Performance Excellence. https://pqa.dti.gov.ph/uploads/resources/2017-2021-pqa-business-criteria-50.pdf

Shrouty, V., \& Tiwari, P. (2017). Business Excellence : A Comparative Study of Various Models, Criteria's and Awards: International Research Journal of Engineering and Technology (IRJET), 4(6), 38-44.

Talwar, B. (2011). Comparative study of framework, criteria and criterion weighting of excellence models. Measuring Business Excellence, 15(1), 49-65. https://doi.org/10.1108/13683041111113240

Tan, K. C. (2002). A comparative study of 16 national quality awards. TQM Magazine, 14(3), 165171. https://doi.org/10.1108/09544780210425874

TCVN Vietnam. (2016). Hương Dẫn Doanh Nghiệp Viết Báo Cáo Tham Dự Giải Thuởng Chất Luợng Quốc Gia. http://dosttn.gov.vn/Files/Images//2021/04/03/Hướng dẫn xây dựng báo cáo tham dự giải thưởng chất lượng quốc gia.pdf

Tickle, M., Mann, R., \& Adebanjo, D. (2016). Deploying business excellence - success factors for high performance. International Journal of Quality \& Reliability Management, 33(2), 197230. https://doi.org/10.1108/IJQRM-10-2013-0160

Toma, S.-G., \& Marinescu, P. (2018). Business excellence models: a comparison. Proceedings of the International Conference on Business Excellence, 12(1), 966-974. https://doi.org/10.2478/picbe-2018-0086

Thailand Quality Award. (TQA) (2018). TQA Criteria for Performance Excellence Framework 2018-2019. Thailand Quality Award. https://qm.kku.ac.th/downloads/TQA61-62.pdf 